\title{
A Case of Cervical Pott's Disease Presenting as Huge Retropharyngeal Abscess
}

\author{
Seon Min Jung, Sang Gyu Park, Hee Won Seo, and Yong Bae Ji $\mathbb{D}$ \\ Department of Otorhinolaryngology-Head and Neck Surgery, Hanyang University College of Medicine, Seoul, Korea
}

\section{거대 후인두 농양을 동반한 경추의 Pott병 1예}

정선민 · 박상규 · 서희원 · 지용배

한양대학교 의과대학 이비인후-두경부외과학교실

\author{
Received March 12, 2018 \\ Revised May 16, 2018 \\ Accepted May 21, 2018 \\ Address for correspondence \\ Yong Bae Ji, MD \\ Department of Otorhinolaryngology- \\ Head and Neck Surgery, \\ Hanyang University \\ College of Medicine, \\ 222 Wangsimni-ro, Seongdong-gu, \\ Seoul 04763, Korea \\ Tel $+82-31-560-2368$ \\ Fax $+82-31-566-4884$ \\ E-mail jyb20000@hanmail.net
}

Tuberculous spondylitis, also known as Pott's disease, is a disease involving the spine with progressive destruction. It most commonly involves the thoracic and lumbosacral spine and may result in severe deformity or neurologic deficit. Although cervical spine involvement is rare, it can cause life threatening event. Recently, 70-year-old man presented with progressive dyspnea and dysphagia. Physical examination and radiologic studies showed a huge retropharyngeal abscess with bony erosion and sclerotic change at the adjacent cervical spine. After incision and drainage, it was finally confirmed as a tuberculous abscess. Herein, we report our experience with literature review. Korean J Otorhinolaryngol-Head Neck Surg 2019;62(5):303-6

Key Words Deep neck infection · Pott's disease - Retropharyngeal abscess · Spondylitis · Tuberculosis.

\section{서 론}

결핵(tuberculosis, Tb)은 전 세계에서 2016년에 약 1천만 명이 감염되어 167 만 명이 결핵으로 사망함으로써 사망 원 인으로서는 9 번째를 차지하고 감염성 질환으로는 가장 높은 빈도를 보이는 질환이다. 우리나라에서도 2015년 한 해 동안 2209명이 결핵으로 사망하였으며, 2016년에도 약 3만 명의 결 핵환자가 발생하여, 우리나라에서도 여전히 중요한 비중을 차지하는 질환이다. ${ }^{1-3)}$

결핵은 여러 신체 부위에 감염될 수 있는데, 중추신경계를 침범하는 경우는 전체의 약 $1 \%$ 정도이고, 이 중 절반 이상이 척추에 이환되는 것으로 알려져 있다. 척추 결핵 중 가장 흔한 양상은 결핵성 척추염(tuberculous spondylitis)으로, 척추를 침범하여 서서히 점진적인 파괴가 진행되는 질환이다. 1779년

This is an Open Access article distributed under the terms of the Creative Commons Attribution Non-Commercial License (https://creativecommons.org/licenses/by-nc/4.0) which permits unrestricted non-commercial use, distribution, and reproduction in any medium, provided the original work is properly cited.
Percivall Pott ${ }^{4,5)}$ 가 전형적인 결핵성 척추염을 Pott병(Pott's disease)이라고 명명하였으며, 항결핵제의 등장과 함께 드문 질환이 되었지만 아직도 저개발국가에서는 주요 질환 중 하 나이다.

Pott병은 다른 신체 부위, 주로 폐에서 기원한 혈행성 전파 를 통해 발생하며, 척추에 감염된 뒤에는 감염된 두 척추 사 이의 추간판으로 번지기도 한다. 호발 부위는 하부 흥추 및 상 부 요추로 알려져 있으며, 주로 척추체를 침범하나 신경 궁이 나 척추 돌기 등도 침범할 수 있다. 또한 감염이 척추체 후방 으로 진행되어 척추관을 침범함으로써 신경학적 이상이 나 타내기도 한다. ${ }^{4-6-8}$

저자들은 최근 호흡곤란과 연하곤란을 주소로 내원한 환 자에서 거대 후인두 농양을 치료하고, Pott병으로 확진된 1예 를 항결핵제를 이용해 성공적으로 치험하였기에, 이를 문헌 고찰과 함께 보고하고자 한다. 


\section{증 례}

70세 남환이 2달 전부터 서서히 시작하여 내원 당일 급격 히 심해진 호흡곤란 및 삼킴곤란을 주소로 응급실을 내원하 였다. 거동이 힘들 정도로 점점 심해지는 전신 무력감이 동반 되었으며, 발열 및 오한은 없었다. 과거력상 기저질환으로 당 뇨가 있었으나 그 외에 특이사항은 없었다.

응급실에서 시행한 신체 검사상 호흡 시 뚜렷한 천명(stridor) 이 동반되어 있었으며, 앙와위에서 호흡곤란이 심해졌다. 폐 전반에 걸쳐 거친 수포음이 청진 되었으나, 발열은 없었고 산 소 포화도는 정상을 유지하고 있었다. 구강 및 인두에는 백 색반과 화농성 분비물이 다량 관찰되었고, 후두 내시경에서 인두 후벽의 종창으로 기도가 매우 좁아져 있었지만 성대 움 직임은 양호하였고 후두개 부종은 관찰되지 않았다(Fig. 1).

혈액학적 검사상 White blood cell(WBC) 10400, Hemoglobin/Hematocrit 12.1/36.8, C-reactive protein(CRP) 16.84, alanine aminotransferase(ALT)/aspartate aminotransferase (AST) 38/27, blood urea nitrogen(BUN)/Creatinine 11/0.5, Glucose 143 등으로 염증 소견 외에 특이사항은 없었다.
응급실에서 시행한 경부 전산화단층촬영상 주변의 조영증 강을 동반한 약 $17 \times 5 \times 5 \mathrm{~cm}$ 의 저음영 부위가 후인두 공간에 서 관찰되었으며, 인접한 척추체들의 미란 및 경화가 관찰되 었다(Fig. 2). 흥부 단순 방사선 촬영상 우측 폐 상엽에 다발성 경화 소견이 관찰되어 활동성 결핵이 의심되었다. 이에 결핵성 척추염에 동반된 후인두 농양이 가장 의심되었으며, 화농성 척추염이 감별되어야 한다고 판단하였다. 호흡곤란이 진행하 는 양상이었기 때문에 응급 절개 배농술을 계획하였다. 기도 삽관이 불가능할 때를 대비하여 응급 기관절개술을 준비한 상태에서 기도 폐쇄를 예방하기 위해 근이완제를 최소한으로 사용하여 마취 유도를 시작하였으며, 기도 삽관이 성공하여 안정적인 상태에서 수술을 시작하였다.

Boyle Davis 개구기(mouth gag, Sculape India; Jalandhar, Punjab, India)를 거치하자 팽륜된 인두 후벽이 관찰되었다. 환자를 트렌델렌버그 위(trendelenburg position)로 위치한 후 인두 후벽에 세로 절개를 가하였다. 절개 직후 다량의 화농성 액체가 쏟아져 나왔으며, 일부 골성 부유물(bony materials) 이 관찰되었다. 농양은 세균배양검사를 의뢰하였으며, 배농 후 후인두 공간에서 괴사성 조직을 채취하여 조직 검사를 의
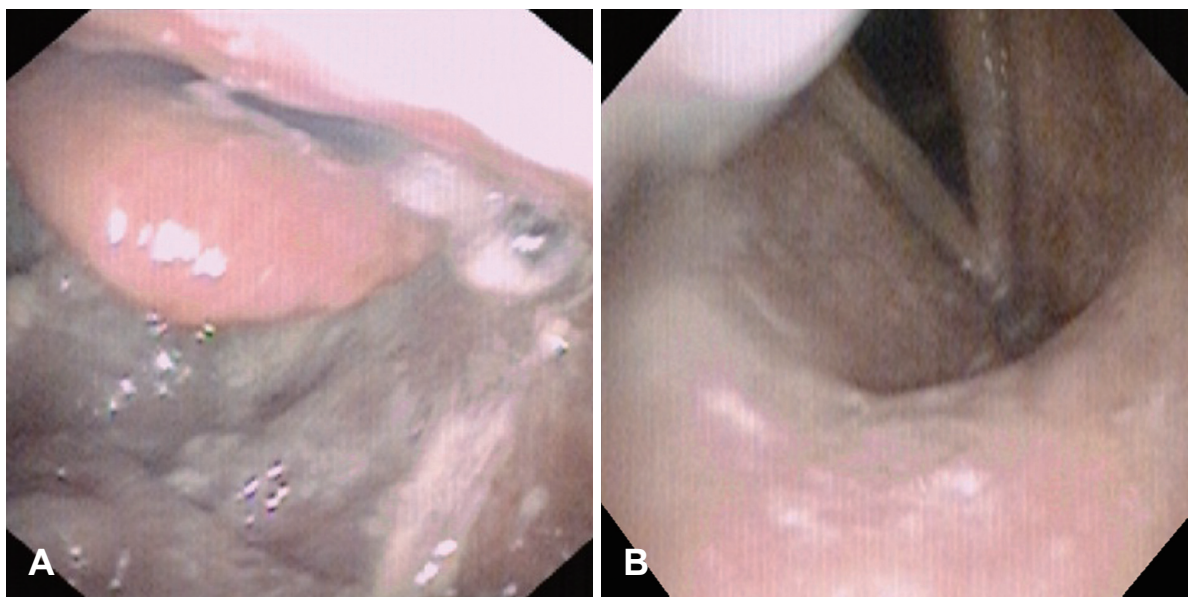

Fig. 1. Endoscopic findings. Upper airway narrowed at the level of epiglottis due to bulged posterior pharyngeal wall $(A)$. The movement of vocal cord and its appearance was relatively intact $(B)$.
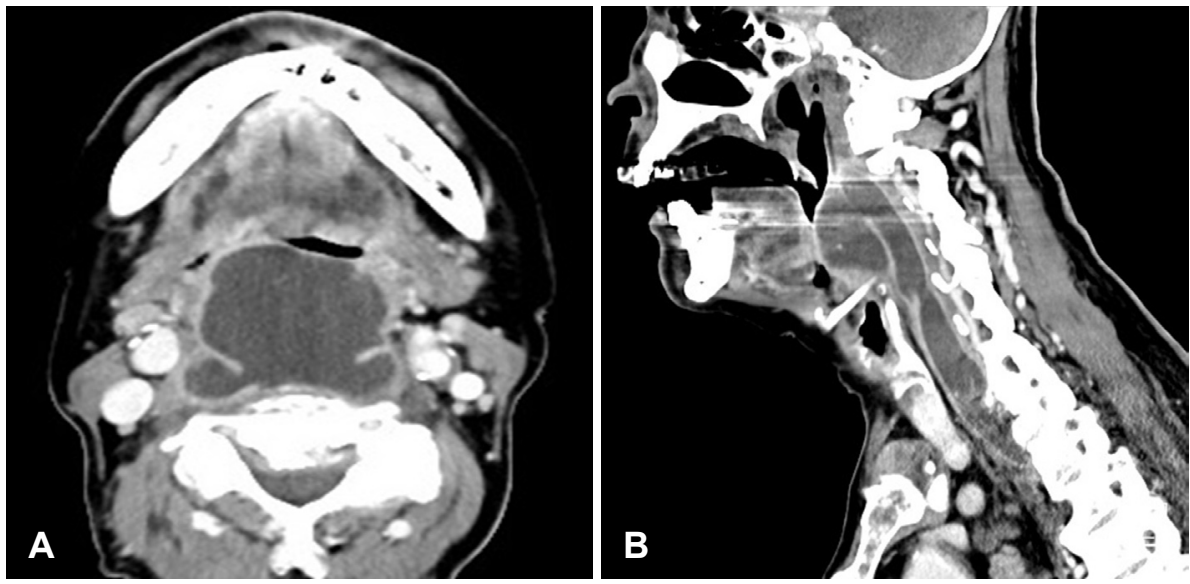

Fig. 2. Preoperative computed tomography scan shows about $17 \times$ $5 \times 5 \mathrm{~cm}$ sized low attenuated lesion at prevertebral and retropharyngeal space from $\mathrm{C} 1$ to $\mathrm{T} 1$ level. Bony erosion with sclerotic change of $\mathrm{C} 3-\mathrm{C} 5$ vertebral bodies was accompanied ( $A$ and $B$ ). 
Fig. 3. Posterior pharyngeal wall bulging and laryngitis were improved in postoperative computed tomography scan (A and $B)$.
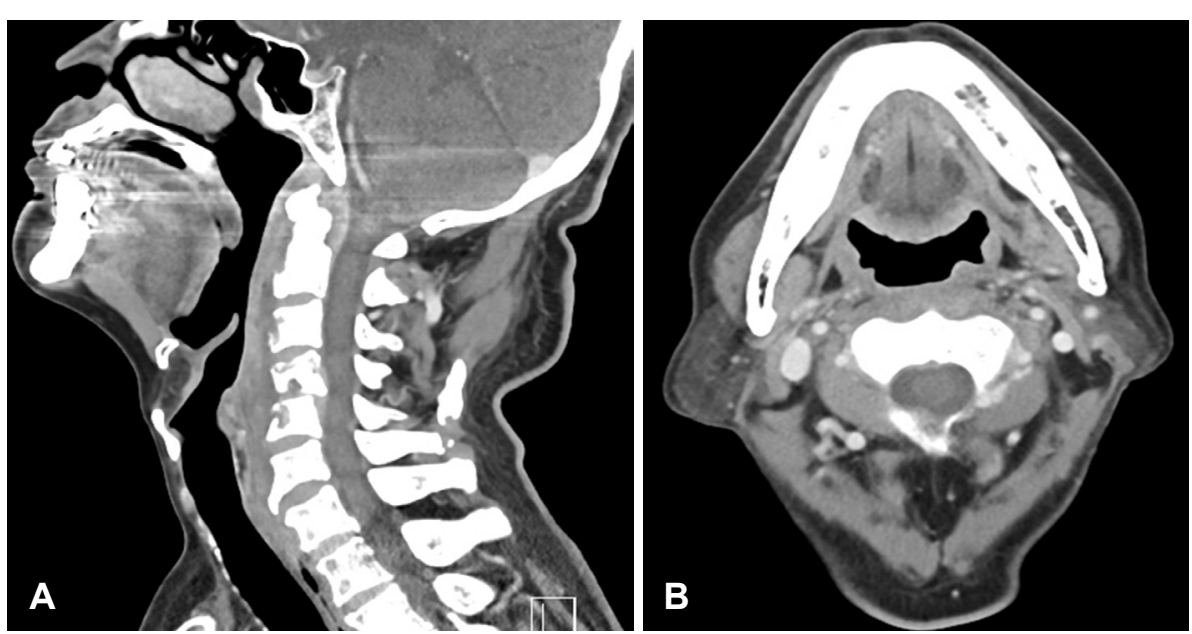

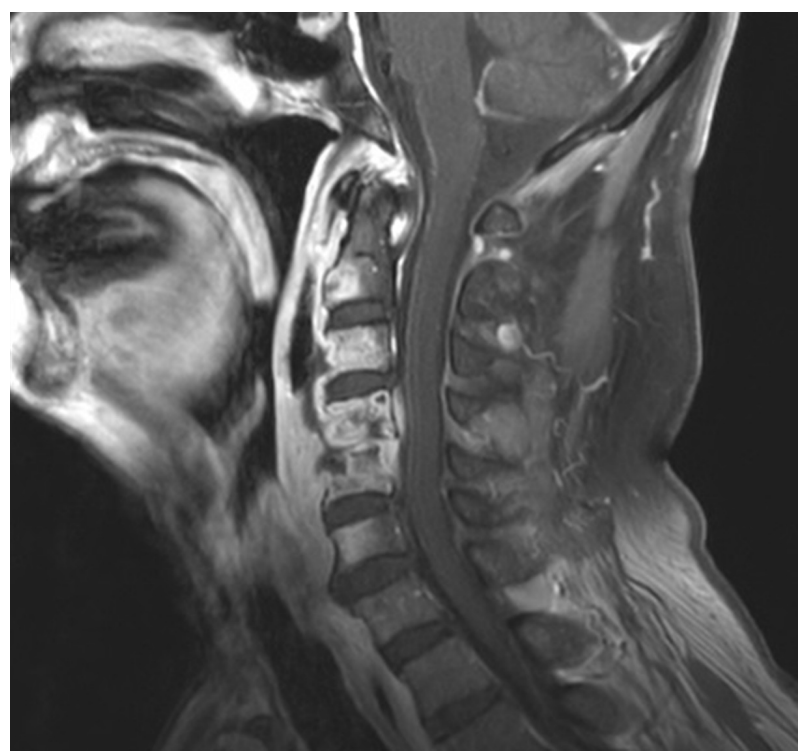

Fig. 4. T1 weighted magnetic resonance image shows bone marrow enhancement and bony erosion with sclerotic change of $\mathrm{C}_{3}-$ C5 vertebrae.

뢰하였다. 식염수를 이용한 세척 후에 절개창의 봉합 없이 수 술을 종료하였으며, 배농 이후 인두 후벽의 종창의 대부분 소 실되었기 때문에 기도 삽관은 바로 제거하였으며, 비위관을 삽입하였다.

농양의 세균배양검사에서 대장균(E. Coli) 및 포도상구균 (Staphylococcus aureus)이 동정되었으며, 조직 검사 상 국소 적인 육아종을 동반한 만성 염증과 결핵균 연쇄효소중합반 응(polymerase chain reaction, PCR)에서 양성 소견을 보였 다. 객담 항산균 염색 검사상 강양성을 보였고(3+), 객담 배양 검사상 Mycobacterium tuberculosis가 동정되었다. 환자는 수술 직후부터 경정맥 항생제와 비위관을 통한 항결핵 약을 투약받았다.

환자는 수술 직후부터 호흡곤란은 대부분 호전되었고 후두
내시경에서 관찰되던 후인두벽 종창도 대부분 소실되었다. 절개 창은 곧 치유되었으나 연하곤란으로 술후 10 병일째까지 경관 급식 유지 후 비위관을 제거하였고, 이후 경구식이가 가능하였 다. 수술 4주 후 추적 관찰한 경부 전산화단층촬영에서도 이전 에 관찰되던 농양은 모두 소실되었다(Fig. 3). 척추 병변에 의한 신경합병증 평가를 위해 경추 자기공명영상을 함께 시행하였 으며 C2-T1 골수의 음영 증가 및 C3-C5 경추의 골경화를 동 반한 골미란 소견과 경미한 척수 압박이 관찰되었다(Fig. 4).

이후 환자는 객담 acid fast bacillus 염색에서 3회 연속 음 성을 보인 30병일에 퇴원하였다. 이후 외래에서 추적 관찰하 며 통해 경구 항결핵제 투여를 지속하였으며, 9 개월간 항결핵 제 투여 후 영상의학적으로 더 이상의 활동성 병변이 관찰되 지 않아 치료 종결하였다.

\section{고 찰}

후인두 공간은 앞쪽으로는 협인두근막(buccopharyngeal fascia), 뒤쪽으로는 익상근막(alar fascia)으로 구분 지어지는 공간으로, 이 부위에 발생한 농양을 후인두 농양이라고 부른 다. 이는 항생제의 사용으로 그 빈도가 감소 중이나 상기도 폐쇄, 흡입성 폐렴, 하행성 종격동염, 패혈증 등의 합병증이 발생하면 생명을 위협할 수 있으므로 즉각적인 진단 및 치료 가 필수적이다. 후인두 농양의 유발 원인으로는 상기도나 구 강 내 감염, 기관 내 삽관이나 내시경 검사 시 인두벽의 외상, 식도이물 등이 있으며 당뇨 등 전신질환이 동반된 경우에는 그 빈도가 높아진다. 임상적 증상 및 징후는 동통, 연하곤란, 방사통, 고열 등이 있다. 후인두 농양의 치료로는 기도확보 및 항생제 치료를 포함하는 보존적 치료와 절개 배농술 등의 수술적 치료가 있다. ${ }^{9}$

척추의 결핵은 대부분 척추체의 망상골에서 시작되며, 최 
초 병변의 발생 기전은 결핵성 동맥내막염(endarteritis)의 형태 로 시작된다. 병리학적으로 척추의 전측부에서 서서히 진행하 여 척추체 주위에 농양을 형성하지만 결핵균은 단백 분해 효 소를 생산하지 않아서 비교적 진행된 경우에만 추간판을 침 범한다. 또한, 병기가 진행되어 급속한 골파괴에 의한 구조적 인 척추기형이나 결핵균의 직접적인 척추관(spinal canal) 침 입 시에는 신경학적 후유증이 발생할 가능성이 증가하여 불 량한 예후를 가져올 수 있다., ${ }^{4,5,710)}$

발병 기전은 주로 혈행성으로 전파되나, 주위 림프절로부 터 파급, 지주막하강으로부터의 파급에 의한 발병도 가능하 며, 원발 부위가 없이 직접적인 결핵균에 의한 일차적 침범에 의해서도 발생할 수 있는 것으로 알려져 있다. 본 증례에서도 결핵균의 혈행성 전파에 의한 척추염이 후인두 공간으로 파 급되었을 가능성이 높지만, 후인두 림프절의 결핵으로부터 척 추염이 발생하였을 가능성도 배제할 수는 없다고 판단된다.

증상으로는 체중 감소, 피로감, 간헐적인 발열감과 같은 전신 증상을 보이고 국소적으로 동통, 근육의 긴장, 약화, 운동 범위 의 감소, 척추 농양의 촉지, 신경증상 그리고 척추 변형 등이 나 타난다. 경추에 발병하는 경우 한냉농양(cold abscess)이 후방삼 각부(posterior triangle of neck), 후인두부(retropharyngeal region), 쇄골 상부에 형성되는 경우가 있으며, 기도와 식도의 압박에 의한 증상이 나타나 심한 경우 사망에 이르게 된다. ${ }^{5,11}$

하지만 Pott병은 대부분 흥추나 요추를 침범하며, 경추를 침 범하는 경우는 매우 드물어 초기의 의심하기가 쉽지 않다. ${ }^{6}$ 따 라서 임상적 소견을 통해 결핵을 의심하는 것이 빠른 진단을 위해 필요하며, 세침흡인검사와 $\mathrm{Tb}-\mathrm{PCR}$ 을 시행하는 것이 진 단에 도움을 줄 수 있다. 세침흡인검사에서 진단이 어려울 경 우에는 생검을 통해 병리조직학적 검사를 시행할 수 있다. ${ }^{4,8,10)}$

Pott병은 척추체 연골 하방의 해면골로부터 감염이 진행되 기 때문에, 전산화단층촬영에서의 척추 소견은 진단에 크게 도움이 된다. 특징은 척추체 전면부의 골 파괴 등이며, 인접 한 여러 척추의 파괴 및 척추체 높이의 감소, 척추 천방 쐐기 의 증가 등도 동반된다. 자기공명영상에서는 피질골 파괴, 골 내 농양, 척추 주위 농양, 경계가 명확한 척추 주위 침범, 염증 의 인대 하 확장, 그리고 비교적 보존된 추간판 등의 소견을 보이며, 이환된 척추뿐 아니라, 척추 주변 연조직과 척추 신경 의 침범에 대해서도 자세히 평가할 수 있다. ${ }^{4}$ 또한 흥부 영상 검사로 폐렴, 흉수, 종격동염 등의 합병증을 확인해야 한다. ${ }^{12)}$

결핵은 대체로 침상안정, 영양 공급, 항결핵제 및 진통제를 통한 보존적 치료가 시행되나, Pott병은 이환된 척추 부위의 추가 손상을 방지하기 위한 보호대가 도움이 되며, 보존적 치 료에 실패하거나, 신경합병증을 동반한 경우, 농양을 형성하 여 배농이 필요한 경우에는 수술적 치료가 필요하게 된다. ${ }^{13)}$
본 증례에서도 서서히 진행하다 심해진 호흡곤란과 신체 검사 및 영상의학적 소견으로 결핵을 의심하였다. 호흡곤란 해결을 위한 즉각적인 절개 및 배농을 시행함과 동시에 조직 검사 및 $\mathrm{Tb}-\mathrm{PCR}$ 을 함께 시행하여 빠른 시간 내에 결핵을 확진할 수 있었다. 환자는 수술 직후부터 호흡곤란이 호전되 었으며, 영상 검사 및 후두 내시경 검사상 호전을 확인할 수 있었다. 이후 항결핵제 치료와 함께 경부와 폐결핵이 함께 호 전되는 소견도 확인할 수 있었다.

경추의 결핵성 척추염이 드문 경우이기는 하지만 대한민국 이 아직은 결핵의 유병률이 높은 점을 감안할 때 척추체의 파 괴를 동반한 후인두 농양이 관찰되는 경우 결핵성 척추염을 반드시 감별진단에 포함하여야 한다. 빠른 진단을 통해 즉각 적인 치료를 시행함으로써 이환율 및 사망률, 합병증의 감소 를 기대할 수 있을 것이다.

\section{ORCID}

Yong Bae Ji

https://orcid.org/0000-0002-0182-7865

\section{REFERENCES}

1) World Health Organization. Global tuberculosis report 2017. [online] 2017 Dec [cited 2017 Sep 10]. Available from: http://www.who.int/ tb/publications/global_report/en/.

2) 2) Korea centers for disease control and prevention. Annual report on the notified tuberculosis in Korea 2016. [online] 2016 Mar [cited 2017 Sep 10]. Available from : http://cdc.go.kr/CDC/cms/cmsFileDownload. jsp?fid $=51 \&$ cid $=67374 \&$ field Name $=$ attach $1 \&$ inde $x=1$.

3) Bynum H. Spitting blood. the history of tuberculosis. Oxford: Oxford University Press;2012. p.6-10.

4) Turgut M. Spinal tuberculosis (Pott's disease): its clinical presentation, surgical management, and outcome. A survey study on 694 patients. Neurosurg Rev 2001;24(1):8-13.

5) Hugar BS, Chandra YP, Babu PR, Jayanth SH, Vinay J. Fatal case of retropharyngeal abscess associated with Pott's disease. J Forensic Leg Med 2013;20(6):567-9.

6) Attia M, Harnof S, Knoller N, Shacked I, Zibly Z, Bedrin L, et al. Cervical Pott's disease presenting as a retropharyngeal abscess. Isr Med Assoc J 2004;6(7):438-9.

7) Janssens JP, de Haller R. Spinal tuberculosis in a developed country. A review of 26 cases with special emphasis on abscesses and neurologic complications. Clin Orthop Relat Res 1990;257:67-75.

8) Le Page L, Feydy A, Rillardon L, Dufour V, Le Hénanff A, Tubach F, et al. Spinal tuberculosis: a longitudinal study with clinical, laboratory, and imaging outcomes. Semin Arthritis Rheum 2006;36(2):124-9.

9) Kim YS, Park JH, Chun SS, Han DY, Kim JE, Lee BD [Clinical analysis of deep neck infection]. Korean J Otorhinolaryngol-Head Neck Surg 2010;53(10):627-31.

10) Kwon C, Sohn JH, Yoo YS, Park K. [A case of retropharyngeal tuberculosis presenting as a huge cystic lesion]. Korean J Otorhinolaryngol-Head Neck Surg 2016;59(12):869-72.

11) Garg A, Wadhera R, Gulati SP, Kishore D, Singh J. Giant retropharyngeal abscess secondary to tubercular spondylitis. Indian J Tuberc 2009;56(4):225-8.

12) Kim SY, Hong SJ, Lee CY, Chung KB, Park CM. [Tuberculous spondylitis vs pyogenic spondylitis: focusing on the discriminative MR findings for differentiation]. J Korean Radiol Soc 2007;56(2):183-9.

13) Lee HS, Jeong JH, Tae K, Park CW, Hong DK. [Surgical treatment of tuberculous cervical abscess]. Korean J Otolaryngol-Head Neck Surg 2000;43(5):540-4. 